\title{
紫外線吸収剂の理論と新規物質開発の考え方 \\ Theory of UV Absorbers and Molecular Design for Novel UV Protective Agents
}

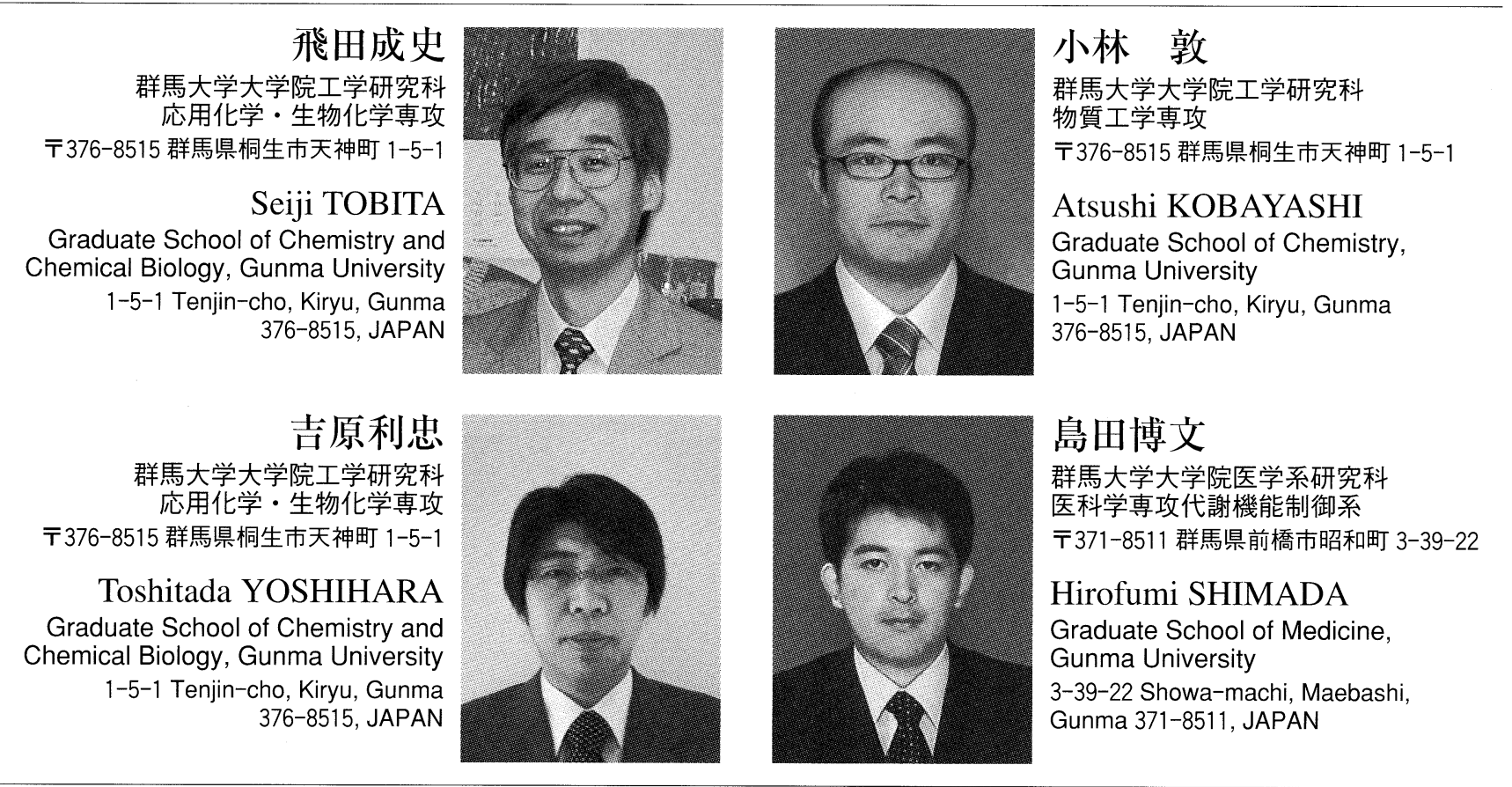

論文要旨：紫外線吸収剂は，皮虐を太陽光紫外線から守るサンスクリーン，高分子の光劣化を防御する光 安定剂等に広く用いられている。本総説では, 市販の紫外線吸収剤の作用機構を励起状態における失活機構 に焦点をあてて考察，体系化し，新規物質開発の考え方について提案する。

\begin{abstract}
Radiationless transitions play a key role in the action of UV absorbers which attenuate the transmission of the solar UV rays to the skin by absorbing the radiation (sunscreen) and prevent polymers from photodegradation caused by UV light (polymer photostabilizer). In this article, mechanistic aspects of UV absorbers, especially the mechanism of the energy dissipating processes in the excited states, have been reviewed, and a guideline for the design of new UV protective agents is presented.

Key words: UV absorbers, sunscreen, internal conversion, triplet state, photoisomerization, proton transfer
\end{abstract}

\section{1 はじめに}

人間活動による化学物質の大気中への放出により, 成 層圈オゾン層の破壊が進んでいる。その結果, 太陽から 地表にふり注ぐ紫外線量が増大し人体への悪影響が危惧 されている。肌をこの有害な紫外線から守るための化粧 品として開発されたのがサンスクリーンである。サンス クリーンには, $\mathrm{TiO}_{2}$ や $\mathrm{ZnO}$ のように紫外線を反射また

連絡者: 飛田成史

E-mail : tobita@chem-bio.gunma-u.ac.jp
は散乱して防御する“物理的フィルタ”と，有機化合物 による紫外線の吸収を利用した“化学的フィルタ”があ る。Fig. 1 に現在，サンスクリーンあるいは高分子安定 剤として使用されている代表的な有機系紫外線吸収剂分 子の構造を示す。本総説では，これまで開発されてきた 紫外線吸収剂の作用機構を光化学の観点から理解, 整理 し，より優れた紫外線吸収剤を開発するための指針を提 案する。 


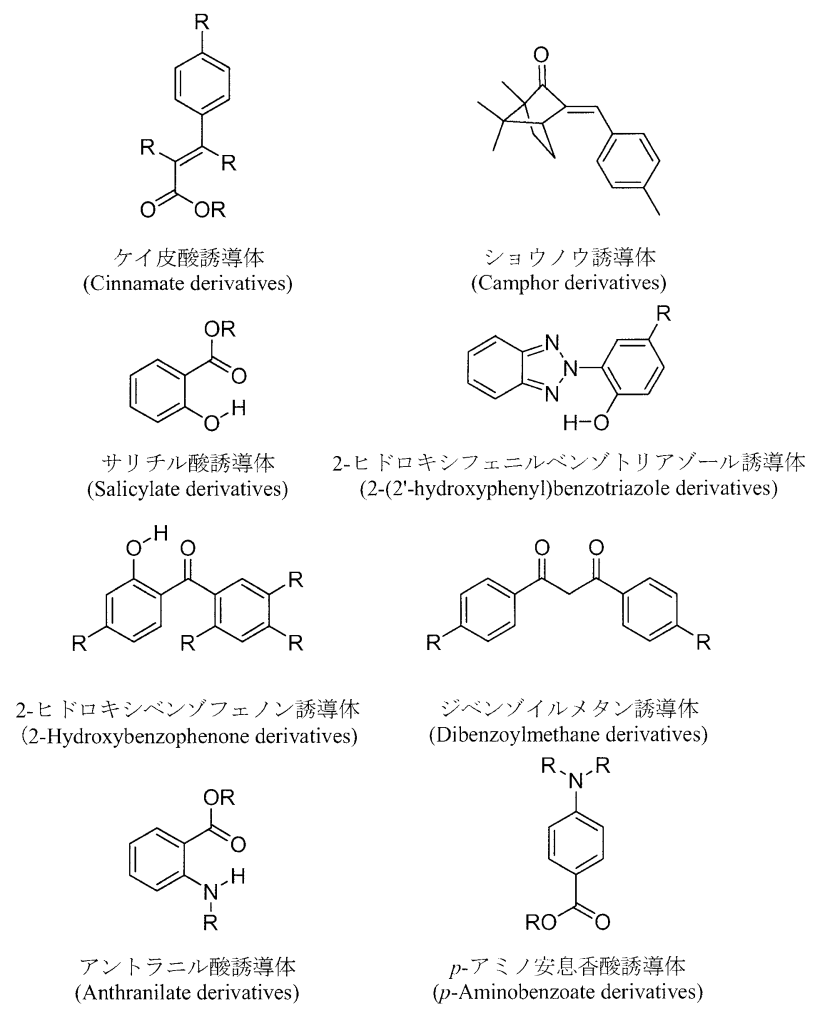

Fig. 1 代表的な紫外線吸収剂分子の構造

\section{2 光の吸収と励起分子の生成}

分子による光の吸収は，光と電子の相互作用すなわち 電子遷移にともなって起こる。電子遷移は，遷移に関与 する電子の軌道によっていくつかに分類される。Figure 2 にベンゾフェノンを例にして，代表的な電子遷移の型 を示す。ベンゾフェノンのようなカルボニル化合物は, 分子中に $\sigma$ 軌道， $\pi$ 軌道に加えて $\mathrm{n}$ 軌道（非結合性軌 道）をもっており，基底状態では， $\mathrm{n}$ 軌道，結合性 $\pi$ 軌 道，結合性 $\sigma$ 軌道に 2 個の電子がスピンの向きを逆向き にして充填した電子配置を取っている。 $\mathrm{n}$ 軌道の電子が 反結合性の $\pi^{*}$ 軌道に励起されると $\mathrm{n} \pi^{*}$ 励起状態， $\pi$ 軌道 の電子が $\pi^{*}$ 軌道に励起されると $\pi \pi^{*}$ 励起状態，同様に $\sigma$ 軌道の電子が反結合性の $\sigma^{*}$ 軌道に励起されると $\sigma \sigma^{*}$ 励 起状態と呼ばれる励起状態が生成する。通常， $\sigma \sigma^{*}$ 励起 には高いエネルギーを必要とするため，その吸収は $\mathrm{n} \pi^{*}$ 吸収， $\pi \pi^{*}$ 吸収に比べてずっと短波長部に現れる。また， $\mathrm{n} \pi^{*}$ 遷移は $\mathrm{n}$ 軌道と $\pi^{*}$ 軌道の空間的な重なりが小さいた めに禁制遷移となり，吸収確率が小さい。一方， $\pi \pi^{*}$ 遷 移は許容遷移であり吸収確率が大きい。紫外線吸収㓮で はこの $\pi \pi^{*}$ 吸収を利用して光を効率よく吸収している。 こうして生じた励起状態のエネルギー関係を示した図を 分子のエネルギー状態図あるいは Jablonski（ヤブロン スキー）戝と呼んでいる。光化学現象を考えるときにた
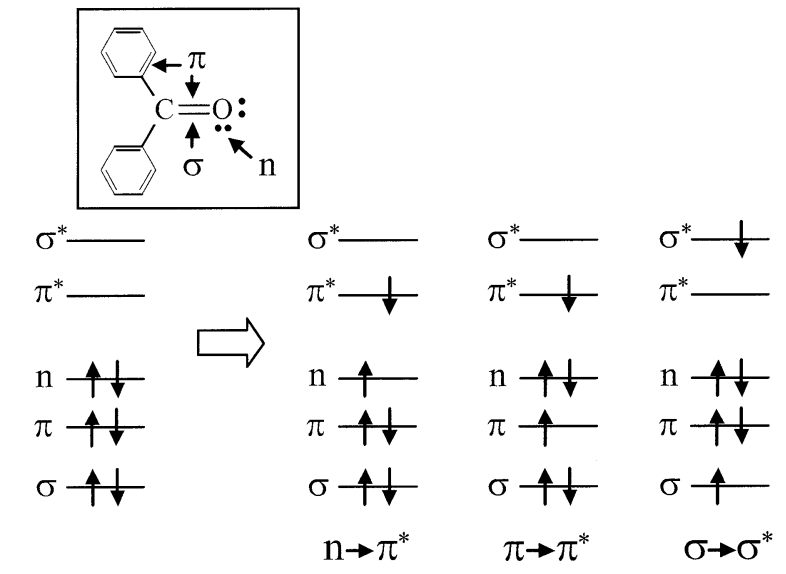

基底状態の電子配㯰

Fig. 2 電子遷移の型 $\left(\mathrm{n} \pi^{*}, \pi \pi^{*}, \sigma \sigma^{*}\right.$ 遷移 $)$

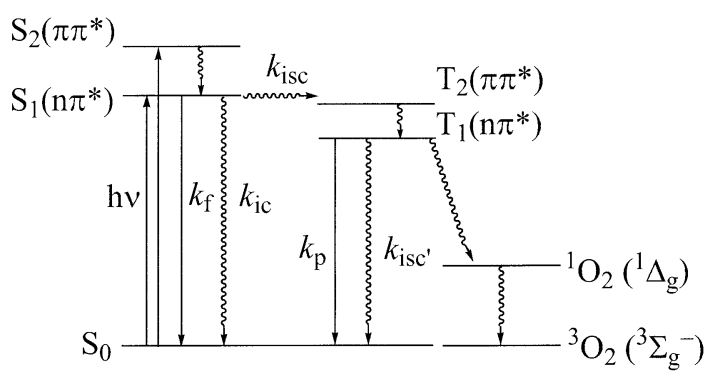

Fig. 3 ベンゾフェノンのエネルギー状態図と励起状態緩和 過程

いへん便利な図である。

Figure 3 にベンゾフェノンのエネルギー状態図を示 す。Figure 2 では電子がスピンの向きを保ったまま高い 軌道に励起しているが，このようにして生じた励起状態 を励起一重項状態 (excited singlet state) と呼ぶ。これ に対して励起する電子のスピンが反転して逆向きになっ た状態を励起三重項状態 (excited triplet state) とい う。それぞれエネルギーの低い方から順番に $\mathrm{S}_{1}, \mathrm{~S}_{2}, \cdots$, $\mathrm{T}_{1}, \mathrm{~T}_{2}, \cdots$ と略記される。ベンゾフェノンの $\mathrm{S}_{1}, \mathrm{~T}_{1}$ 状態 はどちらも $\mathrm{n} \pi^{*}$ 状態である。

\section{3 励起分子の緩和過程}

光吸収は基底状態 $\left(\mathrm{S}_{0}\right)$ から励起一重項状態 $\left(\mathrm{S}_{1}, \mathrm{~S}_{2}\right.$, …）に起こる。このとき吸収される光子のもつエネル ギー（hv）は，基底状態と励起状態のエネルギー差に等 しい。 $\mathrm{S}_{1}$ 状態は不安定で, 通常の有機分子ではナノ秒 $\left(10^{-9} \mathrm{~s}\right)$ 前後の時間内にまた元の基底状態に戻る。その 㞍り方を励起分子の緩和過程という。 $\mathrm{S}_{1}$ 状態の緩和過程 には光を放射して $\mathrm{S}_{0}$ に戻る蛍光 (fluorescence ; 速度定 数を $k_{\mathrm{f}}$ で表す)，光を放射せずに（無放射的に） $\mathrm{S}_{0}$ 状態 の高い振動準位に移る内部変換（internal conversion； 速度定数 $\left.k_{\mathrm{ic}}\right)$, 同じく光を放射せずに三重項状態の高い 
振動準位に移る項間交差（intersystem crossing ; 速度 定数 $k_{\text {isc }}$ ） と呼ばれる過程が含まれる。 $\mathrm{S}_{1}$ 状態から蛍光, 項間交差, 内部変換によって失活する割合を各過程の量 子収率と呼び，それぞれ $\Phi_{\mathrm{f}}, \Phi_{\mathrm{isc}}, \Phi_{\mathrm{ic}}$ で表す。 $\mathrm{S}_{1}$ からの 分解などの反応がなければ $\Phi_{\mathrm{f}}+\Phi_{\mathrm{isc}}+\Phi_{\mathrm{ic}}=1.0$ となる。 蛍光量子收率 $\Phi_{\mathrm{f}}$ は

$$
\Phi_{\mathrm{f}}=k_{\mathrm{f}} /\left(k_{\mathrm{f}}+k_{\text {isc }}+k_{\text {ic }}\right)=k_{\mathrm{f}} \tau_{\mathrm{f}}
$$

で与えられる。ここで， $\tau_{\mathrm{f}}$ は蛍光寿命すなわち $\mathrm{S}_{1}$ 状 態の寿命を表す。蛍光寿命, 蛍光量子収率の值は実験的 に求めることができるので，(1) 式より $k_{\mathrm{f}}$ の值が求ま る。同様に項間交差の量子収率, 内部変換の量子収率の 值と蛍光寿命を用いて $k_{\text {isc }}, k_{\text {ic }}$ の值を決定することがで きる。これらの值が求まれば, 分子の励起状態緩和過程 を定量的に議論することができる ${ }^{1-7)}$ 。

\section{4 理想的な紫外線吸収剤}

紫外線吸収剂は，一言でいえば光を吸収してそれを無 害な熱に変換する系である。用途によっても異なるが, 次のような条件を満足する化合物が理想的な紫外線吸収 剂となり得る。

（1）近紫外波長領域（280〜 400 nm）にできるだけ 強い吸収を有する。すなわち，紫外線を効率よ く吸収する。

（2）励起一重項状態から基底状態へ素早く失活し, 光エネルギーを熱エネルギーに効率よく変換す る。

（3）長時間の光照射に対しても安定に働く。すなわ ち，光化学反応生成物を与えにくい。

(4) 溶媒に溶けやすい。

（5）サンスクリーンに応用する場合は，生体に対す る毒性がない。

この中で (2)の励起状態から基底状態へ素早く失活す る過程は特に重要で, 無放射遷移または無放射失活過程 と呼ばれる。現在, 市販されているサンスクリーンや紫 外線安定剤に含まれる紫外線吸収剤分子は，何らかの機 構で励起状態から素早く無放射失活する化合物である。 そこで，次の項で無放射失活の機構について考える。

\section{5 無放射失活の機構}

励起状態における分解のような光化学反応も無放射失 活過程に含まれるが, ここでは, 紫外線吸収剂の作用機 構に関係する過程として, 励起分子が最終的に元の分子 の形に戻るか，あるいは可逆的に異性体に変換する無放 射緩和過程（項間交差, 内部变換, 光異性化反応) につ いて考える。

\section{$5 \cdot 1$ 項間交差}

$\mathrm{S}_{1}$ から $\mathrm{T}_{1}$ への項間交差過程は電子スピンの反転を伴 うため, 一般の分子では速度が遅い。しかし, 分子中に 原子番号の大きい原子（重原子）があると電子の軌道運 動とスピンの間の相互作用（スピン-軌道相互作用）が 働いてスピン反転しやすくなる。すなわち, 項間交差速 度が増加する (重原子効果)。また, ベンゾフェノンの ように $\mathrm{S}_{1}$ が $\mathrm{n} \pi$ 状態である分子は, 項間交差しやすい 性質をもっている。これは, El-Sayed が提案した項間 交差に関する選択則（El-Sayed 則）を用いて説明する ことができる。

$$
\begin{array}{lll}
{ }^{1} \mathrm{n} \pi^{*} \longleftrightarrow{ }^{3} \pi \pi^{*} & { }^{1} \pi \pi^{*} \longleftrightarrow{ }^{3} \mathrm{n} \pi^{*} & \text { (許容遷移) } \\
{ }^{1} \mathrm{n} \pi^{*} \longleftrightarrow{ }^{3} \mathrm{n} \pi^{*} & { }^{1} \pi \pi^{*} \longleftrightarrow{ }^{3} \pi \pi^{*} & \text { (禁制遷移) (2) }
\end{array}
$$

ここで ${ }^{n} \mathrm{n} \pi^{*}$ は一重項 $\mathrm{n} \pi^{*}$ 状態, ${ }^{3} \pi \pi^{*}$ は三重項 $\pi \pi^{*}$ 状態 を表す。ベンゾフェノンは $\mathrm{S}_{1}, \mathrm{~T}_{1}$ ともに $\mathrm{n} \pi$ *状態である が, $\mathrm{S}_{1}$ 準位の近くに $\mathrm{T}_{2}\left(\pi \pi^{*}\right)$ 状態が存在し, El-Sayed 則に従って $\mathrm{T}_{2}\left(\pi \pi^{*}\right)$ 状態への速い項間交差が起こってい ると考えられている（Fig. 3)。ベンゾフェノンは，項間 交差の量子収率がほぼ 1.0 で，蛍光をほとんど示さない。 El-Sayed 則は，項間交差の起こりやすさを予測する上 で有用である。

項間交差を起こしやすい化合物は，紫外線吸収剤とし ては好ましくない。その理由は，項間交差の結果生ずる 励起三重項状態 $\left(T_{1}\right)$ は，寿命が長く水素引き抜き反応 等の反応を起こしやすい性質をもつからである。さらに Fig. 3 に示すように励起三重項状態は，溶存酸素分子 $\left({ }^{3} \mathrm{O}_{2}\right)$ と衝突してエネルギー移動を起こし，反応性の高 い一重項酸素 $\left({ }^{1} \mathrm{O}_{2}\right)$ を生じやすい性質をもつ。一重項 酸素は酸化力が高いため，紫外線吸収剂分子を酸化し活 性を低下させるとともに，生体に対する毒性があるた め，特にサンスクリーンとしては一重項酸素が発生する 系は好ましくない票。

\section{$5 \cdot 2$ 内部変換}

内部変換は $\mathrm{S}_{1}$ から $\mathrm{S}_{0}$ への直接の失活過程であるた め, 励起三重項状態等の反応性の中間状態を与えない。 すなわち，紫外線吸収剂として理想的な失活機構といえ る。内部変換は，厳密には分子が $\mathrm{S}_{1}$ から $\mathrm{S}_{0}$ の高い振動 準位に等エネルギー的に遷移する分子内過程を指し，そ の理論的な速度定数 $k_{\text {ic }}$ は

$$
k_{\mathrm{ic}}=\frac{2 \pi}{\hbar}\left\langle\phi_{\mathrm{S}_{1}}\left|H^{\prime}\right| \phi_{\mathrm{S}_{0}}\right\rangle^{2}\left\langle\chi_{\mathrm{S}_{1}} \mid \chi_{\mathrm{S}_{0}}\right\rangle^{2} \rho
$$

で与えられる ${ }^{6,7)}$ 。ここで， $\phi_{\mathrm{S}_{1}}, \phi_{\mathrm{S}_{0}}$ は，始状態 $\left(\mathrm{S}_{1}\right)$, 終 状態 $\left(\mathrm{S}_{0}\right)$ の電子部分の波動関数, $\chi_{\mathrm{S}_{1}}, \chi_{\mathrm{S}_{0}}$ は $\mathrm{S}_{1}, \mathrm{~S}_{0}$ 状態 の核振動の波動関数, $\rho$ は終状態 $\left(\mathrm{S}_{0}\right)$ の状態密度を表

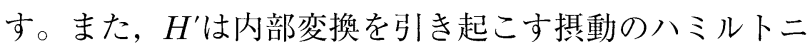


アンと呼ばれ, $\left\langle\phi_{\mathrm{S}_{1}}\left|H^{\prime}\right| \phi_{\mathrm{S}_{0}}\right\rangle,\left\langle\chi_{\mathrm{S}_{1}} \mid \chi_{\mathrm{S}_{0}}\right\rangle$ はそれぞれ電子部 分，振動部分に関する積分を表す。振動の波動関数の重 なり積分の 2 乗 $\left\langle\chi_{\mathrm{S}_{1}} \mid \chi_{\mathrm{S}_{0}}\right\rangle^{2}$ を Franck-Condon 因子と呼 び，通常はこの Franck-Condon 因子の大きさが内部変 換速度を決める重要な因子となっている。

通常の有機分子では, (3) 式の機構による内部変換の 速度は蛍光放射過程に比べて遅い。例えばナフタレンの $k_{\text {ic }}$ は, $1.0 \times 10^{6} \mathrm{~s}^{-1}$ 以下と見積もられ， $k_{\mathrm{f}}$ の值に比べて かなり小さい99。一方，ナフタレンの1-位の水素がアミ ノ基に置換した 1 -アミノナフタレンでは， $k_{\text {ic }}$ が $4.8 \times$ $10^{7} \mathrm{~s}^{-1}$ に増加し，さらに1-(ジメチルアミノ)ナフタレン では, $8.1 \times 10^{9} \mathrm{~s}^{-1}$ となり，さらに著しい増加を示す ${ }^{10,11)}$ 。 この理由は, ナフタレンに比べて1-(ジメチルアミノ) ナフタレンでは, $\mathrm{S}_{1}$ 状態と $\mathrm{S}_{2}$ 状態がエネルギー的に近 接し, $\mathrm{S}_{1}, \mathrm{~S}_{2}$ 状態間の相互作用が生じ, 結果的に $\mathrm{S}_{1} \rightarrow \mathrm{S}_{0}$ 内部変換の Franck-Condon 因子が増加することによっ て説明されている ${ }^{10,12)}$

一般の分子では, 内部変換速度は蛍光放射速度や項間 交差速度に比べて遅いが, 生物系では非常に速い内部変 換を起こす分子がある。DNA に含まれる核酸塩基がそ の例で, アデニン，グアニン，シトシン，チミンは光を 吸収してもほとんど蛍光を示さず， $1.0 \times 10^{12} \mathrm{~s}^{-1}$ 以上の 速さ，すなわち 1 ピコ秒 ( $10^{-12}$ 秒) 以内に直接基底状態 へ内部変換する ${ }^{13)}$ 。遺伝情報を司る核酸塩基が光化学変 化することを巧みに回避している自然界の知恵である。 核酸塩基がどうしてこのような異常に速い内部変換を起 こすのか，たいへん興味が持たれる。Kohler らの最近

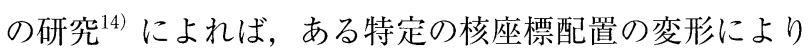
励起状態 $\left(\mathrm{S}_{1}\right)$ と基底状態（ $\mathrm{S}_{0} ）$ のポテンシャル曲面が 交差（円錐交差，conical intersection）し，極めて短い 時間内で失活すると解釈されている。

\section{$5 \cdot 3$ 光異性化反応}

スチルベン（Fig. 4）は，シスートランス光異性化反応 を起こす分子としてょく知られている ${ }^{15,16)}$ 。トランスース チルベン, シスースチルベンは, 室温で流動性の高い溶 媒中では, 蛍光量子収率 $\Phi_{\mathrm{f}}$ が非常に小さく励起状態の 寿命も短い ${ }^{6)}$ 。すなわち, 室温では $\mathrm{S}_{1}$ からの蛍光放射よ りも速い無放射失活過程が存在する。溶媒の粘度を大き

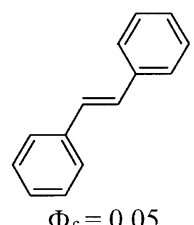

$\Phi_{\mathrm{f}}=0.05$

trans-stilbene

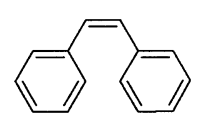

$\Phi_{\mathrm{f}}=0.00$

cis-stilbene

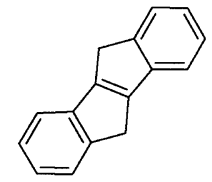

$\Phi_{\mathrm{f}} \cong 1.0$

indeno[2,1-a]indene
Fig. 4 スチルベンとその誘導体の構造と蛍光量子収率
くするか，あるいは温度を低下させると蛍光量子収率の 值が著しく増大する。一方, 中央の二重結合の回りの分 子内回転を抑制したモデル化合物 indeno $[2,1-\mathrm{a}]$ indene では，室温でも $\Phi_{\mathrm{f}}$ の值はほぼ 1.0 になり温度効果も見ら

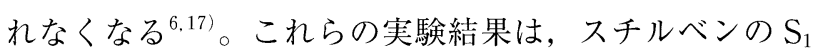
からの速い無放射過程が中央の二重結合でのシスートラ ンス異性化反応によることを示している。

スチルベンのシスートランス光異性化反応は, Fig. 5 に 示すポテンシャルエネルギー曲線を用いて理解すること ができる。基底状態ではねじれ角 $\theta$ が大きくなると $\pi$ 結 合が不安定化するため，トランス型とシス型の間には大 きなエネルギー障壁が存在する。一方, $\mathrm{S}_{1}\left(\pi \pi^{*}\right)$ 励起状 態では, $\pi$ 電子が結合性軌道から反結合性の $\pi^{*}$ 軌道に励 起されるため, 二重結合は, むしろ 90 度ねじれた構造 の方が安定になる。その結果, 90 度㸚じれた構造から 基底状態に速やかに緩和し，トランス型もしくはシス型 の基底状態に戻る。

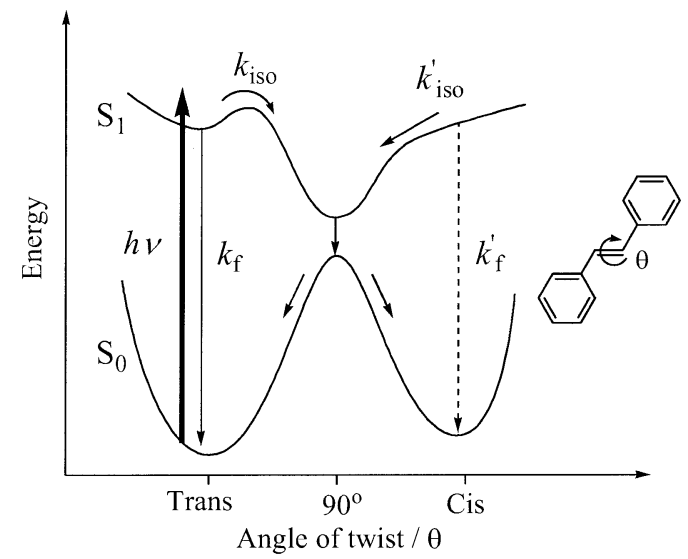

Fig. 5 トランス-スチルベンの光異性化反応のポテンシャル エネルギー図

励起状態分子内プロトン移動反応による速い無放射失 活過程もエノール型からケト型への光異性化反応とみな すことができる。これについては次の項で詳しく述べ る。

\section{6 紫外線吸収剤の作用機構}

次に現在使用されている代表的な紫外線吸収剂の作用 機構について，これまで明らかにされているところを概 観する。

\section{$6 \cdot 1$ 分子内水素結合系}

高分子用光安定剂として使われている2-ヒドロキシ フェニルベンゾトリアゾール誘導体， 2-ヒドロキシベン ゾフェノン誘導体，サリチル酸誘導体は，どれも分子内 に水素結合をもつ系である。これらの化合物はいずれも ほとんど蛍光を示さず，励起状態から速やかに無放射失 
活する。その失活機構は, 光励起によって起こるプロト ン移動サイクルによって説明できる。Elsaesser らは2(2'-hydroxy-5'-methylphenyl) benzotriazole (Tinuvin P）について，フェムト秒レーザーパルスを使った過渡 吸収測定を行い，Fig. 6 のような緩和機構を明らかにし ている ${ }^{18-20)} 。$

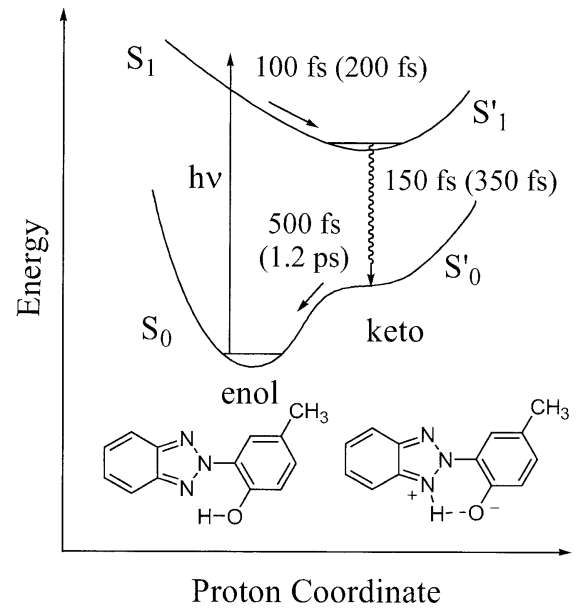

Fig. 6 Tinuvin P の励起状態分子内プロトン移動反応

エノール型の $\mathrm{S}_{1}$ 状態からの分子内プロトン移動反応 は，有機溶媒中では $100 \mathrm{fs}$ (ポリスチレン中では $200 \mathrm{fs}$ ） で起こりケト型の励起状態 $\mathrm{S}_{1}{ }^{\prime}$ が生成する。 $\mathrm{S}_{1}{ }^{\prime}$ は 150 fs （350fs）という非常に短い時間内に $\mathrm{S}_{0}$ ' 入無放射失活し, 約 $500 \mathrm{fs}(1.2 \mathrm{ps})$ で元の $\mathrm{S}_{0}$ ヘ逆プロトン移動する。こ こで $1 \mathrm{fs}$ (1 フェムト秒) は，10 $0^{-15}$ 秒である。すなわち， Tinuvin P のプロトン移動サイクルは $1 \mathrm{ps}$ （10 $10^{-12}$ 秒）以 内に完結する。一般に, 分子内プロトン移動反応は $1 \mathrm{ps}$ 以内で起こる超高速反応であることが分かっており，項 間交差よりもはるかに速い。したがって，プロトン移動 によって生ずる互変異性体の励起状態 $\mathrm{S}_{1}{ }^{\prime}$ が高効率で無 放射失活すれば，理想的な紫外線吸収剂となり得る。 Tinuvin P が極めて短い時間内に失活する理由として, 互変異性体の励起状態 $\mathrm{S}_{1}$ ' と基底状態のポテンシャルが 交差 (円錐交差) して高速に内部変換する機構が提案さ れている ${ }^{21,22) 。}$

2-ヒドロキシベンゾフェノンは, ベンゾフェノンと類 似の分子構造を有するが, 励起状態の緩和過程は全く異 なる ${ }^{23-27)}$ 。ベンゾフェノンは $5 \cdot 1$ で述べたように量子収 率ほぼ 1 で $\mathrm{T}_{1}$ へ項間交差するが，2-ヒドロキシベンゾ フェノンは， $n$-ヘキサンのような非水素結合性溶媒中で は， $\mathrm{S}_{1}$ から基底状態へ約 $35 \mathrm{ps}$ で速やかに失活し， $\mathrm{T}_{1}$ 状 態には緩和しない。2-ヒドロキシベンゾフェノンの場合 は，励起状態プロトン移動反応を直接観測した報告例は 見られないが，分子内水素結合が速い内部変換を誘起し
ていることは間違いないようである ${ }^{27,28)}$ 。たとえば，工 タノールのような水素結合性溶媒中では，一部の分子が 溶媒と分子間水素結合を形成し内部変換速度が遅くなる ため， $\mathrm{T}_{1}$ 状態が生成することが報告されている ${ }^{24)}$ 。

\section{$6 \cdot 2$ シスートランス光異性化反応}

ケイ皮酸誘導体は UVB 領域（280〜 $320 \mathrm{~nm})$ に $\pi \pi^{*}$ 遷移による強い吸収帯をもつためUVB 領域のサンスク リーンとして現在，広く用いられている。代表的な化合 物として，パラメトキシケイ皮酸エチルヘキシル（2ethylhexyl-4-methoxycinnamate) (OMC) のトランス 異性体 (trans-OMC) とシス異性体 (cis-OMC) の構 造式を Fig. 7 に示す。この化合物も光を吸収すると, 速 やかに無放射失活し基底状態に戻る。無放射失活する機 構は, Fig. 7 に示した異性体間のシスートランス光異性化 反応である。trans-OMC を光励起するとプロペニル二 重結合がねじれ，Fig. 5 と同様のポテンシャル面に沿っ て緩和し元のトランス型あるいはシス型の基底状態を生 成する。この光異性化反応は可逆的に起こり，光定常状 態ではシスートランス平衡となる。trans-OMC と $\mathrm{cis}^{-}$ OMC はどちらも UVB 領域に強い吸収を示すが，シス 体の方が分子吸光係数が小さい ${ }^{29)}$ 。サンスクリーンのよ うな高濃度の条件下では可逆的なシスートランス光異性 化反応に加えて, 不可逆な反応も起こり, 紫外線吸収剂 としての性能低下をきたすことが報告されている゙0)。不 可逆な反応として，まずプロペニル二重結合での $2+2$ 光二量化反応が起こることが知られている。また，この 不可逆反応の寄与は，溶媒の極性や溶存酸素の効果を受 ける ${ }^{8)}$ 。溶存酸素存在下では光照射とともに吸収効率が 減少してくることから，励起分子の一部が項間交差して 一重項酸素を生成し酸化反応（光酸化反応）を受けてい ると考えられている ${ }^{8,30)}$ 。

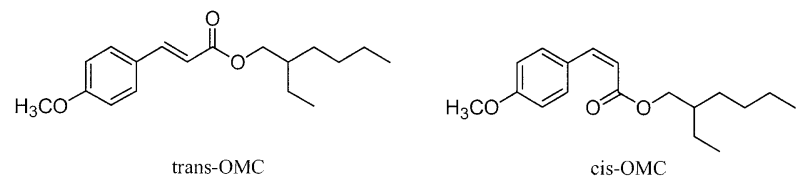

Fig. 7 トランス型，シス型ケイ皮酸エチルヘキシルの分子 構造

\section{$6 \cdot 3$ ジベンゾイルメタン誘導体}

ジベンゾイルメタン（DBM）とその誘導体は，溶液 中では, Fig. 8 に示すようなケトーエノール互変異性体と して存在する。

エノール体は分子内水素結合形成による電子的な安定 化により，ケト体に比べて存在比が大きいことが知られ

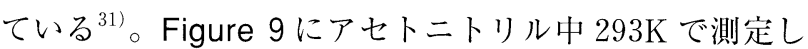
た（a）DBM，（b）カルコン，（c）2,2-ジベンゾイルプ 


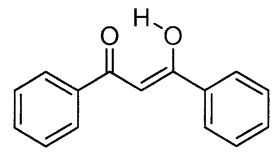

enol form

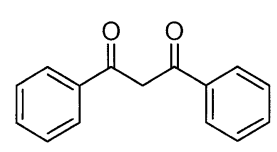

diketo form
Fig. 8 ジベンゾイルメタンのエノール型, ケト型構造と ケトーエノール平衡

ロパンの吸収スペクトルを示す。ここで 2,2 -ジベンゾイ ルプロパンの吸収スペクトルは，近似的にDBM のケト 体の吸収スペクトルに等しいとみなすことができる。 Figure 9 から DBMのエノール体の第一吸収带は，ヶト 体に比べて大きくレッドシフトし, 遷移確率も増加して いることが分かる。吸収極大波長 $(340 \mathrm{~nm})$ におけるモ ル吸光係数は $2.24 \times 10^{4} \mathrm{dm}^{3} \mathrm{~mol}^{-1} \mathrm{~cm}^{-1}$ である。吸収波長 の長波長化とモル吸光係数の増大は, 分子内水素結合に よって 6 員環状擬 $\pi$ 電子系が形成された結果であり,

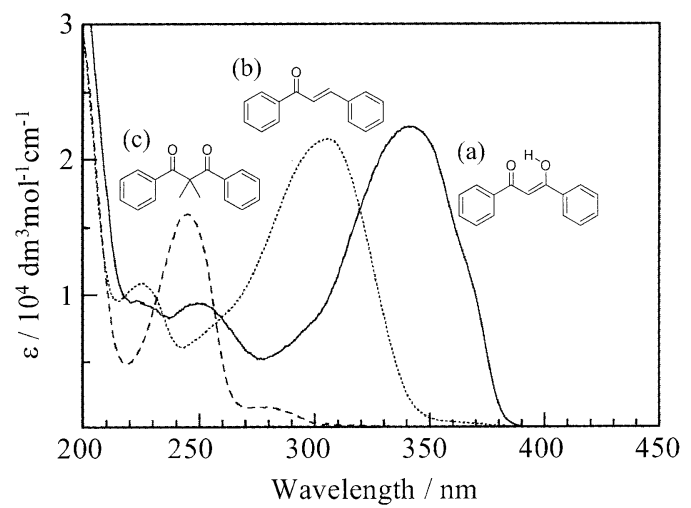

Fig. 9 (a) ジベンゾイルメタン， (b) カルコン， (c) 2,2-ジベ ンゾイルプロパンの吸収スペクトル（溶媒：アセト ニトリル)

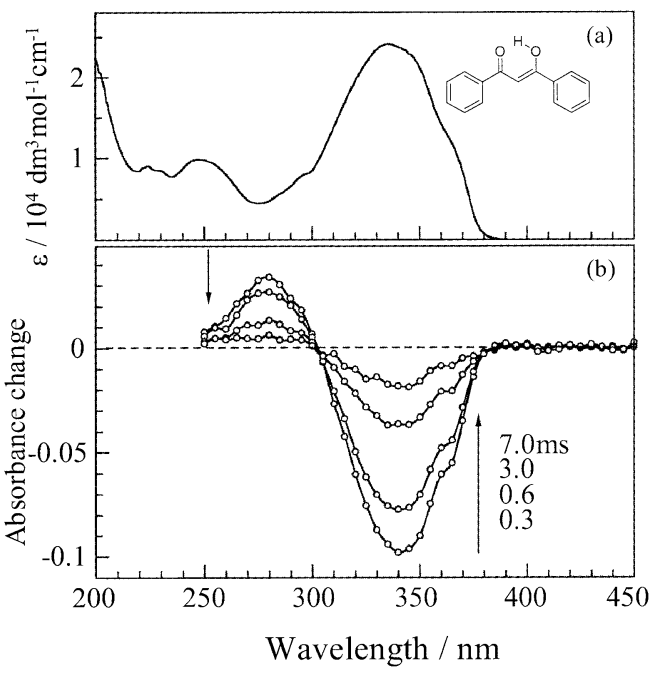

Fig. 10 n-ヘキサン中におけジベンゾイルメタンの (a) 吸収 スペクトルと (b) $355 \mathrm{~nm}$ ナノ秒レーザー励起で得ら れた過渡吸収スペクトル（温度：293K）
DBM が効率よく UVA 光（320〜 $400 \mathrm{~nm} ）$ を吸収する 要因となっている。

DBM は光励起してもけい光を全く示さない。これは, $\mathrm{S}_{1}$ 状態から蛍光放射過程と競合する何らかの非常に速い 無放射失活過程が存在するためである。もし，項間交差 によって励起三重項状態が生成していれば，過渡吸収測 定によって $\mathrm{T}_{1}$ 状態の吸収（T-T 吸収）が観測されるは ずである。そこで，DBM の過渡吸収スペクトルを 293 K，n-ヘキサン中で測定した結果を Fig. 10(b)に示す ${ }^{32) 。 ~}$ $340 \mathrm{~nm}$ に極小值をもつ負の吸収帯は，DBM の基底状態 の吸収スペクトル（Fig. 10(a)）とほぼ鏡像関係にある ことから，基底状態のブリーチングに帰属できる。275 $\mathrm{nm}$ 付近には過渡吸収帯が見られる。この吸収帯の減衰 速度は，溶存酸素の影響を受けないことから，励起三重 項状態ではなく，基底状態中間体によると考えられる。 さらに，この中間体の減衰速度とブリーチングの回復速 度が一致していることから，この中間体は元のエノール 型 DBM に戻っていることが分かる ${ }^{32)} 。$

以上の結果は，DBM の励起一重項状態で非常に速い 構造変化が起こり何らかの中間体が生成し，それがゆっ くりと元の chelated-enol (CE) form に戻るという光サ イクルが起こっていることを示唆している。Cantrell ら ${ }^{33)} は 4-t e r t-b u t y l-4$ '-methoxydibenzoylmethane (BM-DBM）について，ナノ秒過渡吸収測定を行い, DBM と非常に類似した結果を得ている。過渡吸収の解 析から BM-DBM の励起状態について Fig. 11 のような 緩和機構を提案している。まず $\mathrm{CE}$ の $\mathrm{S}_{1}$ 状態でキレー 卜内 $\mathrm{C}=\mathrm{C}$ 二重結合のねじれにより non-chelated enol (NCE) form が生成する。 NCE 体は低濃度では単分子的 にゆっくりと元の CE 体に戻るが，レーザーパワーを高 くして濃度を増すと，分子間水素結合体の生成を経て 2

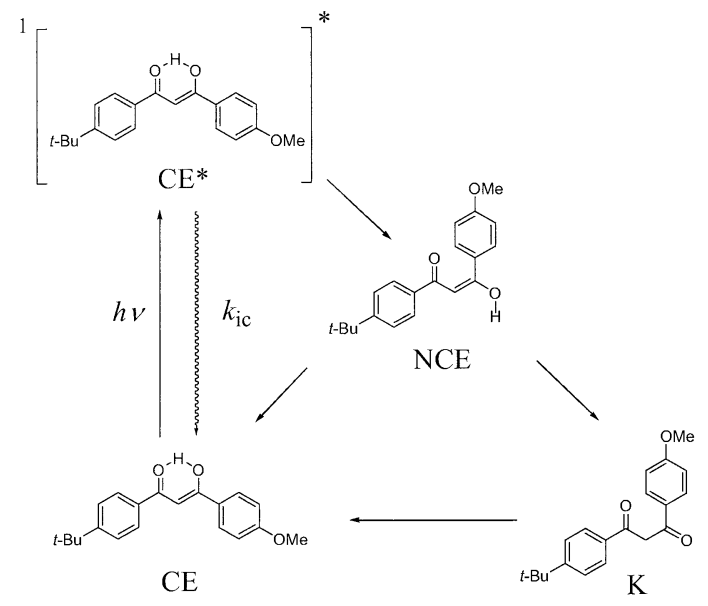

Fig. 11 4-tert-butyl-4'-methoxydibenzoylmethane (BM-DBM) の励起状態緩和機構 
分子的に元の CE 体に戻る。この際，一部がケト体 $(\mathrm{K})$ に異性化し，このケト体が光分解を起こしているようで ある。NCEの分子構造はカルコンに類似していること から，CE 体に比べて吸収がブルーシフトすると予測さ れる。Fig. 10 の中間帯の過渡吸収スペクトルはこの予想 とも一致している。Nakata ら ${ }^{34)}$ はアセチルアセトンの 低温アルゴンマトリクス中での光異性化反応をフーリエ 変換赤外分光法を用いて研究し, 極低温 $(15 \mathrm{~K})$ におけ る紫外線照射でも Fig. 11 の $\mathrm{CE}^{*} \rightarrow \mathrm{NCE}$ と同様の異性 化反応が起こっていることを報告している。

アントラニル酸誘導体, $p-$ アミノ安息香酸誘導体は, 励起状態プロトン移動反応, 光異性化反応のような特別 な無放射緩和を起こさないため, $\Phi_{\mathrm{f}}$ が大きく, 項間交差 によって $T_{1}$ 状態を生じる ${ }^{35,36)}$

\section{7 新しいタイプの紫外線吸収剤}

既存の紫外線吸収剂における光エネルギーから熱エネ ルギーへの変換は，(3) 式に基づく内部変換に加えて励 起状態におけるシスートランス異性化反応，分子内プロ トン移動反応等による高効率の無放射失活過程を利用し ていることが理解できた。一方，核酸塩基は， $\mathrm{S}_{1}$ ポテン シャル曲面と $\mathrm{S}_{0}$ ポテンシャル曲面の円錐交差によって 超高速緩和を起こす。すなわち生物における紫外線防御 機構では，既存の紫外線吸収剂とは全く異なる機構が働 いており，もっと効率が高く，副反応も少ない。核酸塩 基と同様の機構ですばやく失活し，しかもUVBもしく はUVA 領域に強い吸収を与える化合物があれば，理想 的な紫外線吸収剂と言えよう。

一方，最近われわれは 2 -アミノアセトフェノン誘導 体が励起状態から効率良く無放射失活し，紫外線吸収剂 としての性質を有することを見出した ${ }^{37}{ }^{38)}$ 。Figure 12 は (a) アセトフェノンと (b) 2'-アミノアセトフェノンの吸 収スペクトルを示している。アセトフェノンはベンゾ フェノンと同様に $\mathrm{S}_{1}, \mathrm{~S}_{2}$ がそれぞれ $\mathrm{n} \pi^{*}, \pi \pi^{*}$ 状態で，基 底状態からこれらの状態への吸収が $325 \mathrm{~nm}, 280 \mathrm{~nm}$ 付 近に観測される。 $\mathrm{S}_{1}\left(\mathrm{n} \pi^{*}\right)$ 状態と $\mathrm{S}_{2}\left(\pi \pi^{*}\right)$ 状態のエネル ギーギャップは $7,300 \mathrm{~cm}^{-1}$ ある。一方，2'-アミノアセ卜 フェノンではアミノ基の電子的効果によって $\mathrm{S}_{2}\left(\pi \pi^{*}\right)$ 状 態が安定化し，第一吸収帯が長波長へシフトするととも

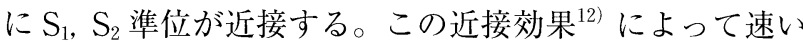
内部変換が誘起される。この傾向は，アミノ基の水素の 一方をメチル化した 2'-(methylamino) acetophenone (MAAP) においてより顕著に現れ，第一吸収帯の極大

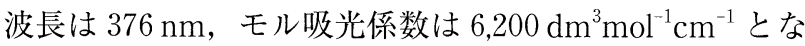
り, UVA 領域に強い吸収をもつ。MAAP の蛍光量子収 率は $n$-ヘキサン中, $293 \mathrm{~K}$ において 0.023 で蛍光寿命も

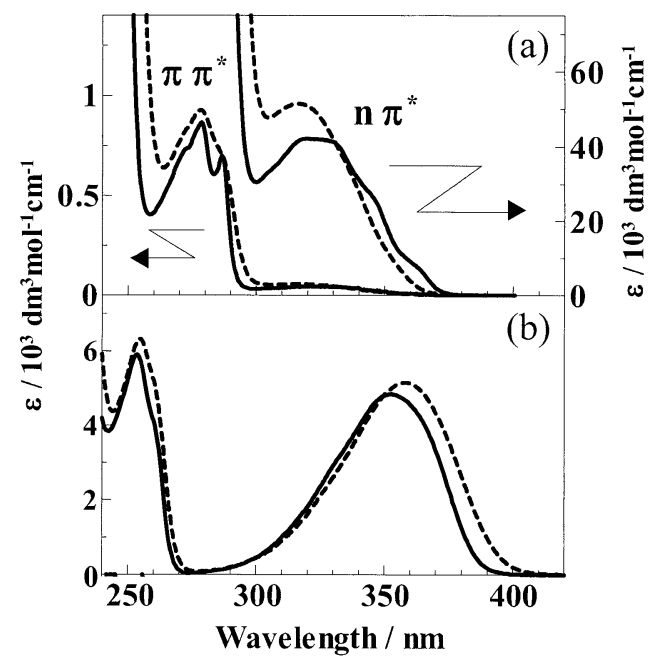

Fig. 12 (a)アセトフェノン, (b)2'アアミノアセトフェノンの nーヘキサン中（実線），アセトニトリル中（破線） の吸収スペクトル

9.4 ps と通常の分子に比べて非常に短い。また，項間交 差の量子収率が 0.02 以下と見積もられたことから，速い 内部変換によって失活していることがわかる。

\section{8 おわりに}

既存の紫外線吸収剤は, 光化学的な作用機構によって いくつかのタイプに分類できることを述べた。今後より 優れた性質を有する紫外線吸収剂を開発するための研究 の一つの方向は，既存のシステムの問題点をその作用機 構に立ち返って再検討し，これを改良することにある。 たとえば，分子内水素結合系は，極性が高く塩基性の環 境下では，分子間水素結合の形成によって分子内水素結 合が切れ光安定性を失うことが問題になっている。その 解決策として，ヒドロキシル基のオルト位に嵩高い置換 基を導入すると，極性環境でも分子内水素結合が保たれ 光安定性が増すことが報告されている ${ }^{39)}$ 。もう一つの方 向として，自然界に倣って円錐交差や近接効果を利用し た全く新しい夕イプの紫外線吸収剤分子を開発する方向 が考えられる。

\section{文献}

1）伊藤道也，レーザー光化学一基礎から生命科学まで一, 裳華房 (2002).

2）井上晴夫，高木克彦，佐々木政子，朴鐘振，光化学 I, 丸善 (1999).

3）杉森彰, 光化学, 裳華房 (1998).

4) B. Valeur, Molecular Fluorescence, Wiley-VCH: Weinheim (2002).

5) J.R. Lakowicz, Principles of Fluorescence Spectroscopy, Kluwer Academic/Plenum, New York, ed. 2. (1999).

6) N.J. Turro, Modern Molecular Photochemistry, Ben- 
jamin/Cummings (1978).

7) J.B. Birks, Photophysics of Aromatic Molecules, Wiley, London (1970).

8) J.M. Allen, C.J. Gossett \& S. K. Allen, Chem. Res. Toxicol, 9, 605-9 (1996).

9) K. Takehira, K. Suzuki, H. Hiratsuka \& S. Tobita, Chem. Phys. Lett., 413, 52-8 (2005).

10) K. Suzuki, H. Tanabe, S. Tobita \& H. Shizuka, J. Phys. Chem. A, 101, 4496-503 (1997).

11) K. Suzuki, A. Demeter, W. Kühnle, E. Tauer, K.A. Zachariasse, S. Tobita \& H. Shizuka, Phys. Chem. Chem. Phys., 2, 981-93 (2000).

12) E.C. Lim, J. Phys. Chem., 90, 6770-7 (1986).

13) C.E. Crespo-Hernández, B. Cohen, P.M. Hare \& B. Kohler, Chem. Rev., 104, 1977-2019 (2004).

14) P.M. Hare, C.E. Crespo-Hernández \& B. Kohler, Proc. Natl. Acad. Sci. USA, 104, 435-40 (2007).

15) D.H. Waldeck, Chem. Rev., 91, 415-36 (1991).

16) P.M. Felker \& A.H. Zewail, J. Phys. Chem., 89, 5402-11 (1985).

17) J. Saltiel, O.C. Zafirious, E.D. Megarity, \& A.A. Lamola, J. Am. Chem. Soc., 90, 4759-60 (1968).

18) M. Wiechmann, H. Port, W. Frey, F. Laermer \& T. Elsaesser, J. Phys. Chem., 95, 1918-23 (1991).

19) C. Chudoba, S. Lutgen, T. Jentzsch, E. Riedle, M. Woerner \& T. Elsaesser, Chem. Phys. Lett., 240, 35-41 (1995).

20) C. Chudoba, E. Riedle, M. Pfeiffer \& T. Elsaesser, Chem. Phys. Lett., 263, 622-8 (1996).

21) C.M. Estévez, R.D. Bach, K.C. Hass \& W.F. Schneider, J. Am. Chem. Soc., 119, 5445-6 (1997).

22) V. Kozich, J. Dreyer \& W. Werncke, Chem. Phys. Lett., 399, 484-9 (2004).

23) W. Klöpffer, Adv. Photochem. 10, 311-58 (1977).
24) S.-Y. Hou, W.M. Hetherington III, G.M. Korenowski \& K.B. Eisenthal, Chem. Phys. Lett., 68, 282-4 (1979).

25) C. Merritt, G. W. Scott, A. Gupta \& A. Yavrouian, Chem. Phys. Lett., 69, 169-73 (1980).

26) J.C. Scaiano, Chem. Phys. Lett., 92, 97-9 (1982).

27) T. Okazaki, N. Hirota \& M. Terazima, J. Phys. Chem. A, 101, 650-5 (1997).

28) J. Catalán \& J.C. del Valle, J. Am. Chem. Soc., 115, 4321-5 (1993).

29) S.P. Huong, V. Andrieu, J.-P. Reynier, E. Rocher, \& J.-D. Fourneron, J. Photochem. Photobiol., A: Chem. 186, 65-70 (2007)

30) G.J. Smith \& I.J. Miller, J. Photochem. Photobiol., A: Chem., 118, 93-7 (1998).

31) M. Moriyasu, A. Kato \& Y. Hashimoto, J. Chem. Soc. Perkin Trans. II, 515-20 (1986).

32) S. Tobita, J. Ohba, K. Nakagawa \& H. Shizuka, J. Photochem. Photobiol., A: Chem., 92, 61-7 (1995).

33) A. Cantrell and D.J. McGarvey, J. Photochem. Photobiol., B: Biol., 64, 117-22 (2001).

34) N. Nagashima, S. Kudoh, M. Takayanagi \& M. Nakata, J. Phys. Chem. A, 105, 10832-8 (2001).

35) A. Beeby \& A.E. Jones, J. Photochem. Photobiol., B: Biol., 64, 109-16 (2001).

36) A. Beeby \& A. E. Jones, Photochem. Photobiol., 72, 10-5 (2000).

37) T. Yoshihara, H. Shimada, H. Shizuka \& S. Tobita, Phys. Chem. Chem. Phys., 3, 4972-8 (2001).

38) H. Shimada, A. Nakamura, T. Yoshihara \& S. Tobita, Photochem. Photobiol. Sci., 4, 367-75 (2005).

39) P.F. McGarry, S. Jockusch, Y. Fujiwara, N.A. Kaprinidis \& N.J. Turro, J. Phys. Chem. A, 101, 764-7 (1997). 